\title{
Book review: MARINA VIGÁRIO, SÓNIA FRITA \& M. JOÃO FREITAS (eds.), Phonetics and phonology: Interactions and interrelations (Current Issues in Linguistic Theory 306) - CORRIGENDUM
}

David Deterding

doi:10.1017/S002510031600013X, published by Cambridge University Press, 22 March 2016.

The author of this book review apologies for the error in one of the book editors' names.

Sónia Frita should be Sónia Frota.

\section{Reference}

David Deterding. Book review of Marina Vigário, Sónia Frita \& M. João Freitas (eds.), Phonetics and phonology: Interactions and interrelations (Current Issues in Linguistic Theory 306). Journal of the International Phonetic Association. Published by Cambridge University Press, 22 March 2016. doi:10.1017/S002510031600013X. 